\title{
Folkebiblioteket i flervidenskabelig belysning
}

\author{
Leif Kajberg anmelder en antologi af symposiebidrag med spændende \\ perspektiver på svensk biblioteksforskning
}

Biblioteksstudier : folkbibliotek i flervetenskaplig belysning / [ed] Romulo Enmark. - Göteborg: Centrum för biblioteksforskning, 1990. - $212 \mathrm{~s}$. (Skrifter från föreningen "Bibliotekshögskolan och Centrum för biblioteksforskning publicerar" ; 1). ISBN 91-971457-0-X

Biblioteksstudier indeholder bidragene til et symposium, der blev afholdt på initiativ af Forskningsrådsnämden, der i Sverige yder økonomisk støtte til biblioteksforskningen. Symposiet blev gennemført i maj 1989 i samarbejde med Centrum för biblioteksforskning vid Göteborgs universitet, der også har stået for udgivelsen af symposierapporten (med tilskud fra Forskningsrådsnämden).

Symposiet tema var "folkebiblioteket i tværfaglig" (eller multi-disciplinær) belysning - i god overensstemmelse med den folkebiblioteksorienterede forskningsprofil, der satses på af Centrum för biblioteksforskning og dets dynamiske leder Romulo Enmark. Enmark sidder på en ensom men vigtig post i Göteborg som katalysator, iværksætter, formidler og tusindkunstner.

I Jan Hagerlids komprimerede men udmærkede indledning gives en kort præsentation af det meget differentierede svenske biblioteksforskningslandskab, der rent geografisk har et tyngdepunkt i Göteborgregionen med Centrum för biblioteksforskning i Göteborg, det kommende professorat i biblioteks- og informationsvidenskab ved Göteborgs universitet og biblioteksskolen i Borås, og desuden rummer bastioner som universitetet $i$ Uppsala (litteratursociologi), universitetet i Linköping (Institutionen för pedagogik och psykologi og LIBLAB) og INFORSK ved Umeå universitet. Vigtigt for biblioteksforskningens trivsel er det, at der er skabt et bevillingsmæssigt fundament under biblioteksforskningsaktiviteter i og med at Forskningsrådsnämden har accepteret et ansvar for denne forskning og fra finansåret 1988/89 er begyndt at optræde som et forskningsråd for biblioteksforskning, der formulerer programmer, prioriterer og tager initiativer $\mathrm{på} \mathrm{området.}$ 
Dette svenske symposium og det nu publicerede materiale om folkebiblioteksforskning repræsenterer en betydelig landvinding og et velgørende og konstruktivt syvemileskridt ud af det hængedynd af ørkesløse diskussioner og definitionsforsøg, som i flere år har præget svensk biblioteksforskning. Intentionen har været at give et billede af den forskning omkring folkebiblioteket, som udføres i Sverige og skabe en katalysatoreffekt, der kan føre dette forskningsfelt ind i en ny udviklingsfase. Man valgte at sætte repræsentanter for en række faglige discipliner stævne og bede dem lose en bunden opgave, nemlig besvarelsen af spørgsmảlet: hvad kan forskellige discipliner tilføre folkebiblioteksforskningen $i$ form af teoretiske og metodologiske perspektiver ? Dette valg blev truffet ud fra en erkendelse af, at folkebiblioteket må studeres ud fra mange vinkler, og at folkebiblioteksforsknningen har behov for håndsrækninger fra mere etablerede forskningsfelter, når den forsøger at vinde fodfæste inden for den etablerede akademiske verden. Bogens bidrag giver et klart vidnesbyrd om, at der er mange discipliner, der betragter folkebiblioteket som et interessant og legitimt forskningsobjekt og gerne vil være med til at give dette "embryoniske" forskningsfelt et løft. Adskillige forskere uden for den svenske BDI-sektoren er allerede parthavere i en folkebiblioteksrettet forskning, medens andre har projekter inden for denne forskningsgren $\mathrm{i}$ støbeskeen. Når folkebiblioteket som institution påkalder sig forskningsmæssig interesse fra forskellige etablerede akademiske discipliner, hænger det bl.a. sammen med, at de svenske folkebiblioteker er unikke i kraft af deres stærke tilknytning til folkeoplysningen og traditionen for en aktiv kulturpolitisk rolle. Derfor er det naturligt, at discipliner som literaturvidenskab, litteratursociologi og etnologi interesserer sig for folkebibliotekerne.

Det internationale udblik sikres af Lars Höglund og Olle Persson fra INFORSK i Umeá. De to BDIforskere bevæger sig ud over den snævrere folkebiblioteksreferenceramme i deres opsats, der omtaler en kortlægning af omfanget af den internationale forskningsaktivitet på området biblioteks- og informationsvidenskab, altså BDI-området. Som indikator for den samlede internationale BDIforskningsproduktion anvendes andelen af BDIartikler af det samlede antal artikler, som er regi- streret i databasen Social Science Citation Index. Af de ca. 60.000 artikler, der årligt registreres i basen, hidrører ca. 1.700 fra BDI-tidsskrifter. Denne andel er gået op fra omtrent $2 \%$ i begyndelsen af 1970'erne til ca 3\% i slutningen af 1980'erne. Mere interessant er kortlægningen af Sveriges (og de øvrige nordiske landes) andel af den artikelmasse, der beskæftiger sig med BDI-emner. Vi får herigennem dannet os et indtryk af det fingeraftryk, Norden afsætter på den internationale BDI-forskningsaktivitet. Det er meget beskedent, fremgår det af Höglund \& Perssons bibliometriske undersøgelser. I en 15-års periode har Sverige produceret 86 artikler om BDI-emner, hvilket kun svarer til 0.35 $\%$ af produktionen på verdensbasis. Danmark, Norge og Finland har tilsvarende lave procenter. Det vises, at den svenske andel af BDI-artikelproduktionen gennemgående ligger under det svenske gennemsnit for alle andre forskningsområder i databasen. Set $i$ et internationalt perspektiv kan man konkludere, at Sverige på BDI-området har en relativt svag profil. Som hovedårsager til dette efterslæb peger Umeå-forskerne på det forhold, at BDI som disciplin og forskningsfelt endnu ikke har etableret sig $i$ universitetsmiljøerne, og at faste forskningsressourcer er en mangelvare.

Der er dog et enkelt sted i universitetsverdenen, hvor biblioteksorienteret forskning for alvor har vundet indpas. Det er hos professor Furuland og hans avdelning för litteratursociologi i Uppsala, der blev oprettet i 1965 . Her har man med stor energi kastet sig over folkebiblioteket som forskningsobjekt. Det fremgår af den forskningsoversigt, som er en del af Lars Furulands præsentation af litteratursociologien og dens vinkler på folkebiblioteksforskningen. Man imponeres over bredden og mangfoldigheden $\mathrm{i}$ de projekter, der hidtil er gennemført, og i de aktuelle forskningsaktiviteter. Man interesserer sig i Uppsala meget for analyser af forskellige bibliotekstypers bogbestand, og folkebibliotekets forgængere (læseselskaber, lejebiblioteker, sognebiblioteker) har en fremskudt placering i forskningen ved afdelingen. Desuden dyrkes forlæggerhistorie og bibliotekshistoriske studier, bl.a. børnebibliotekers og skolebibliotekers historie. En anden forskningsretning beskæftiger sig med opsøgende biblioteksvirksomhed, primært arbejdspladsbiblioteker. I 1986 publiceredes således 
en doktorafhandling om arbejdspladsbiblioteker i Sverige (Mats Herder). Furuland runder af med nogle aktuelle forskningspolitiske betragtninger. Efter hans opfattelse er forskning af biblioteker pr. definition tværfaglig, hvorfor denne forskning bedst bedrives i et universitetsmiljø. Lokaliseringen af Bibliotekshögskolan i Borås, der har forårsaget mange rivegilder, må endnu en gang stå for skud denne placering har ikke just medvirket til at fremme svensk biblioteksforskning. Losningen er nu at få gang i et samarbejde mellem Centrum för biblioteksforskning, Bibliotekshögskolan og forskellige institutioner og forskningsgrupper i Göteborgregionen. I det hele taget er etableringen af netværk for biblioteksforskningen af afgørende betydning, mener Furuland.

Men der er andre forskere inden for litteraturvidenskaben, som har en mening om (folke)biblioteksforskning og nogle bud $\mathrm{pa}$, hvad litteraturforskningen kan bidrage med. Kristian Wåhlin gør således rede for de muligheder, der ligger $i$ at bruge receptionsforskningen som instrumentarium. Efter en lidt overflødig, elementært docerende forelæsning om litteraturvidenskaben på den gamle bibliotekskoles grundskoleniveau går Wảhlin over til at skitsere et stort anlagt projekt ved Litteraturvetenskapliga institutionen vid Göteborgs Universitet og med tilknytning til Centrum för biblioteksforskning. Projektet stiller det generelle spørgsmål: hvorfor er visse bøger så populære? Svarene skal søges i bøgerne selv og i lasernes oplevelser af bøgerne. I det omtalte projekt har man valgt at tage udgangspunkt $i$ nogle af de populæreste bøger og opsøge bøgernes læsere. De tre udvalgte titler er børnebøger; med i udvalget er Ole Lund Kirkegaards "Gummi-Tarzan", der også har lagt navn til projektet ("Gummi-Tarzan på biblioteket"). Det indsamlede materiale - båndede interviews med børn bl.a. - vil blive analyseret med udgangspunkt $\mathrm{i}$ teorier om læseprocessen og kulturel reception.

Den idéhistoriske indfaldsvinkel, applikeringen af idéhistoriske teorier og metoder $\mathrm{på} \mathrm{problemkredsen}$ folkebiblioteker og folkeoplysning, tages op til belysning af Björn Olsson, som giver nogle spændende eksempler pá, hvordan studier af de tidlige folkebiblioteksformer - læseforeninger, arbejder-, studiekreds-, forenings- og logebiblioteker og sammensætningen af deres samlinger ved hjælp af materialer som accessionskataloger og udlånsprotokoller kan tjene til at afdække idéspredningsmønstre og de folkelige bevægelsers udvikling. Olsson refererer en interessant punktundersøgelse af tidlige biblioteker i skolebyen Härnösand i 1800-tallet (fra Roger Qvarsells bog "Kulturmiljø og idéspredning"). I Härnösand tog gymnasieeleverne i 1807 initiativ til at oprette deres eget fritstående bibliotek som protestaktion og som modvægt mod den lærdes skoles bibliotek, som var det eneste stedlige bibliotek. En kortlægning af den bogbestand, der fandtes i dette bibliotek i 1790, viser, at de teologiske værker dominerede sammen med afhandlinger på latin og bøger præget af universiteternes humanistiske dannelsestradition. Samtidens videnskabelige og filosofiske arbejder var derimod ikke repræsenteret i skolebiblioteket.

Det er betegnende for "Biblioteksstudier", at tyngden og kvaliteten af oplæg og redegørelser fra de forskellige faglige discipliner er meget varierende. Enkelte af symposiets bidragydere var i stand til at fremlægge detaillerede forskningsoversigter og dokumentere allerede gennemførte folkebiblioteksundersøgelser. Andre har måttet koncentrere sig om skitseforslag og udvikling af projektidéer og forestillinger om de forskningsmæssige muligheder, der findes i skæringspunktet mellem folkebiblioteket og deres egen akademiske disciplin. Det gælder således oplæggene om studier af folkebiblioteksbygninger som en del af offentlighedens arkitektur, folkebiblioteket som forskningsobjekt for erhvervsøkonomi, studiet af informationsteknologiens virkninger $\mathrm{i}$ folkebiblioteksmiljøer $\mathrm{i}$ et kommunikationsteoretisk perspektiv (med "det sociale felt" og "community" som nøglebegreber) og præsentationen af de forskningsopgaver, som kan interessere psykologen. På dette felt - psykologi og BDI-forskning - er der i udlandet gjort et vist forarbejde. Der kan fx henvises til NORDINFO-seminaret om psykologi og informationssøgning i 1983 på Danmarks Biblioteksskole (proceedings publiceret $i$ et temanummer af Social Science Information Studies i 1984).

Talrige eksempler på gennemført og afrapporteret folkebiblioteksforskning findes til gengæld i Maj 
Klassons beskrivelse af pædagogikkens tværvidenskabelige karakter specielt i relation til folkebiblioteksprojekter, og den biblioteksforskning, der tager udgangspunkt i pædagogikkens forskningsmetoder og teorier. Her er der uanede muligheder for forskning; centrale forskningsområder er fx folkebibliotekets rolle i livslang uddannelse, børnebiblioteksvirksomhed og skolebiblioteket rolle. Den historiske dimension kommer ind $\mathrm{i}$ studiet af formuleringerne af folkebibliotekernes formål i relation til livslang uddannelse og i klarlæggelsen af den rolle, som bibliotekerne spillede som redskab i de folkelige bevægelsers kundskabsoffensiv. Bibliotekerne var en del af de folkelige bevægelser og en modbevægelse i samfundet. Maj Klasson er selv centralt placeret i den pædagogisk orienterede biblioteksforskning, der er vokset frem på Linköpings universitet, og kombinationen af docentansættelsen ved institutionen för pedagogik og fagreferentstillingen på universitetsbiblioteket giver hende de bedste forudsætninger for at virke som brobygger mellem pædagogik og BDI-forskning. At der allerede er udrettet temmelig meget pá dette felt, fremgår af redegørelsen og listen over Maj Klassons egen forskningsproduktion, der er meget imponerende.

En rad tråd, der går gennem fle:e af oplæggene, er vægtningen af de kvalitative forskningsmetoder. Bannerfører for de kvalitative metoder er ikke mindst Romulo Enmark, der i sin opsats om folkebiblioteket $i$ et etnologisk perspektiv indleder med en præsentation af fænomenologi og hermeneutik.

En gang var det sådan, at den heftige diskussion i Sverige af biblioteksforskningen og dens lokalisering nærmest kaldte på det overbærende smil. Denne holdning er passé nu; der er så meget i gang i svensk biblioteksforskning og perspektiverne så løfterige, at vi i Danmark bør studere denne forskningsudvikling mere opmærksomt og søge at få skabt flere kontakter til de eksisterende forskningsmiljøer. Det man her i Danmark fra en biblioteksskoleposition måske kunne misunde svenskerne, er den konkurrence og de tværfaglige udfordringer, der udgår fra universitetsmiljøerne. Herhjemme er store dele af biblioteksforskningen jo stort set monopoliseret af Danmarks Biblioteksskole, natio- nale netværk er en mangelvare, og vi har endnu ikke noget forskningsråd. Skal man fremme biblioteksforskning, er afholdelsen af seminarer og møder, der som symposiet i Göteborg er koncentreret om signalementer af potentielle forskningsområder, fremlæggelse af projektforslag og præsentation af igangværende forskning, en god og konstruktiv begyndelse. Man når herigennem udover snakke- og definitionsstadiet og făr etableret nogle rammer, der i første omgang - som det er tilfældet med Göteborg-symposiet - muliggør diskussioner af teori og metode og udveksling af information om projekter. Emin Tengström peger i sine afrundende og opsummerende kommentarer til symposiet og dets papirer på, at det fortsat er uklart, hvordan biblioteksforskning og informationsvidenskab kan afgrænses som et særligt videns- og forskningsområde, og hvor man skal søge denne disciplins/forsknings kærneområder. Dette problem kan efter nærværende anmelders opfattelse først løses på længere sigt i takt med, at man præsterer en konkret forskningsindsats, der giver sig udslag i rapporter og artikler, der underkastes faglig kvalitetsvurdering, "peer review", i nationale og internationale fora inden for BDI-omrádet og máske også udenfor.

Leif Kajberg, konsulent, Danmarks Biblioteksskole 